\title{
The Indochinese Refugee Movement: An Exploratory Case Study of the Windsor Experience
}

\author{
GIOVANA ROMA
}

\begin{abstract}
Following the fall of Saigon in 1975, thousands fled Indochina in small boats to attain political asylum in neighbouring countries. Canada played a leading role in the resettlement of thousands of Indochinese refugees, and a significant part of this national effort was led by the city of Windsor, Ontario. This article examines Windsor's local efforts to sponsor and integrate Indochinese refugees into Canadian society. In late 1977, Windsor Mayor Bert Weeks established an ad hoc committee on Indochinese refugees. Together with volunteers from local faith communities and non-governmental organizations, the city created a vast resettlement network and assumed the sponsorship of several families, well before the wave of refugees arrived in 1979. As an exploratory work, this article provides evidence of Windsor's pivotal role in shaping the Canadian response to the Indochinese refugee crisis and may challenge the national narrative that large Canadian cities led refugee resettlement efforts. This study is timely, as important lessons can be drawn from the Windsor experience.
\end{abstract}

\section{Résumé}

À la suite de la chute de Saigon en 1975, des milliers de réfugiés ont fui l'Indochine dans des petites embarcations en quête d'asile politique dans les pays voisins. Le Canada a joué un rôle de premier plan dans la réinstallation de milliers de réfugiés indochinois, et une partie importante de cette initiative nationale était menée par la municipalité de Windsor, en Ontario. Cet article examine les initiatives locales de la part de Windsor en matière de parrainage et intégration des réfugiés indochinois à la société canadienne. Vers la fin de l'année 1977, Bert Weeks, maire de Windsor, avait établi un comité spécial pour les réfugiés indochinois. En collaboration avec des volontaires issus de communautés religieuses locales et des organismes non gouvernementaux, la municipalité avait créé un vaste réseau dédié à la réinstallation et entrepris le parrainage de plusieurs familles, bien avant l'influx des réfugiés en 1979. En tant que recherche exploratoire, cet article fournit des preuves du rôle déterminant de la municipalité de Windsor dans la formulation de la réaction canadienne à la crise des réfugiés indochinois, et pourrait mettre en question le discours national selon lequel le rôle principal pour les initiatives de réinstallation des réfugiés revenait aux grandes métropoles canadiennes. Cette étude est donc pertinente, étant donné qu'il y a des leçons importantes que l'on pourrait tirer de l'expérience de Windsor.

\section{Introduction}

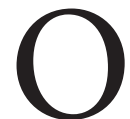
n 30 April 1975, the South Vietnam capital of Saigon was captured by Communist forces, marking the end of the Vietnam War. Cambodia and Laos quickly followed suit, and soon after, all of Indochina was ruled by Communist regimes. ${ }^{1}$ It was the beginning of a new, capricious regional order, which sparked a mass exodus of refugees. Approximately 135,000 Vietnamese fled the country before Saigon collapsed, sparking a humanitarian crisis of global proportions. 
Over 2 million people fled the Indochinese countries of Vietnam, Laos, and Cambodia over the next decade, and approximately 20 million were displaced at one point or another. ${ }^{2}$ Thousands fled in small boats, crossing pirateridden waters in hopes of finding safety in neighbouring countries. In this context, Canada played a leading role in the resettlement of thousands of Indochinese refugees, accepting an estimated 60,000 between 1979 and 1980, and anywhere from 130,000 to 150,000 refugees in total. ${ }^{3}$ At the forefront of this national initiative is the small city of Windsor, Ontario.

In late 1977, Windsor Mayor Bert Weeks established an "ad-hoc committee on Indochinese refugees." Together with volunteers from the local faith communities and non-governmental organizations, the City of Windsor created a vast refugee network and assumed the sponsorship of several families, well before the "flood of refugees" arrived in 1979. This article examines Windsor's local efforts to sponsor and integrate Indochinese refugees into Canadian society and provides evidence that Windsor may have served as a model to other Canadian resettlement efforts, by leading in the resettlement of Indochinese refugees in late 1977-well before the large Canadian cities began to organize themselves in 1979.

\section{Research Methodology}

This case study focuses on the City of Windsor's Indochinese refugee resettlement efforts from 1977 to the early 1990s. Michael Molloy coordinated the Indochinese refugee movement in 1979 and 1980. As president of the Canadian Immigration Historical Society, Michael stumbled upon the Windsor story by chance, as he was digging through national archival records on the Indochinese refugee crisis. There he found a memorandum to Minister Cullen, which cited Windsor's efforts in assisting refugee families. From this, Michael recruited me-a research associate at the University of Windsor-to track down additional clues of the city's precedent-setting involvement in refugee resettlement.

This is an exploratory study, which serves as a cursory introduction to the Windsor experience. Several studies evaluate the Canadian response to the Indochinese refugee crisis. Of note are Neuwirth and Clark (1981), Adelman (1982), Lanphier (1983), Chan and Indra (1987). 4 However, few have written about the experiences at the local levels. Although some sources mention Windsor in passing, no published study provides an in-depth look at the city's Indochinese resettlement model. 5 Such a study is warranted, especially given the evidence that the Windsor program was ahead of its time and received national and regional attention. As is the case with most exploratory studies, the article leaves a lot of questions unanswered. Its main aim is to unveil an untold piece of local (and national) history by exploring the City of Windsor's resettlement model and its possible reach. While the study is not meant to draw firm conclusions, it provides evidence that suggests the Windsor model was avant-garde in its response to the Indochinese movement, and challenges the national narrative that large Canadian cities led refugee resettlement efforts in the late 1970 s and early 1980s. It is hoped that future research can help confirm these suggestions.

For this article, case study research of the Windsor model was conducted from November 2014 to March 2015. Primary and secondary sources were used. Primary sources include archival research and semi-structured informal interviews. First, a number of archives were consulted in order to find primary documents that illuminate the historical period under analysis, starting from 1974 (before the fall of Saigon) to the early 1990s. The archival documents used in this study originate from the Windsor Community Archives at the Windsor Public Library; the Windsor Star Archives; the Edmonton Catholic Social Services; the Catholic Diocese of London; Library and Archives Canada; and personal manuscripts from interviewees. ${ }^{6}$

Next, semi-structured, informal interviews were conducted with eight individuals who were involved in the local resettlement program. Interviewees include volunteers who were directly involved with the process, those close to the leaders of resettlement efforts, and local Indochinese refugees. Interviews were conducted in English, by the author, in person and by telephone. Respondents were selected using the snowballing technique, in which interviewees were suggested by participants. Information gleaned from eight interviews is included in this study.

Secondary information-in the form of peer-reviewed journal articles, government reports, theses, and newspaper articles-provides historical context and an overview of literature on the subject. These texts were obtained through online research databases and local archives. Other individuals and organizations involved in local resettlement were also consulted, including local churches and nongovernmental organizations.?

There were several limitations to this study. Since Windsor's active role in the resettlement of Indochinese refugees occurred 40 years ago, many organizations have permanently closed, and their records have either been destroyed or lost. As the home of Father Warden, St. Joseph's Catholic Church housed most records associated with the Mayor's Ad Hoc Committee and the Windsor Friendship Families. However, this church has since been closed, and all archival records, excluding sacramental certificates, have been destroyed. Another setback in the collection of research is that several leaders involved in the Windsor project, 
including Mayor Bert Weeks and Father Warden have passed away. In order to mitigate these gaps, interviews were conducted with individuals who knew the actors well during this time. Interviewees included Mayor Weeks's former commissioner of finance, his executive assistant, and his daughter. Primary sources, including committee minutes, ${ }^{8}$ letters of correspondence, and local newspaper articles were also used to substantiate interviews.

To commence, this article provides an explanation of the Windsor Indochinese resettlement model, which is broken down into two crucial elements: (1) the Mayor's Ad Hoc Committee on Indochinese Refugees and (2) the Friendship Families. The Windsor model is then situated in the greater historical context, in order to analyze its possible impact and offer suggestions for future research.

\section{Windsor's Indochinese Resettlement Program}

Windsor's manufacturing economy and strong unions gave the New Democratic Party a large support base. As a result, the city boasts one of the first welfare systems in the country and is the home of respected non-profit organizations including United Way and the Windsor Coalition for Development. 9 In the time leading up to the Indochinese refugee movement, Windsor had already played an important role in the resettlement of refugees from Hungary, Hong Kong, Czechoslovakia, Uganda, and Chile, establishing a basis for resettlement efforts to come. ${ }^{10}$

Between 1978 and 1993, the Windsor area resettled over 1,900 government-sponsored Indochinese refugees. ${ }^{11}$ The city's role in the resettlement of hundreds of Indochinese refugees can be divided into two, complementary developments: (1) the Mayor's Ad Hoc Committee on Indochinese Refugees and (2) the Friendship Families program.

First, the Mayor's Ad Hoc Committee on Indochinese Refugees was established in late 1977 by Mayor Bert Weeks. ${ }^{12}$ The committee operated out of the City of Windsor and included city councillors, members of the local faith communities, local and regional representatives from the Canadian government, members from the University of Windsor, and the public school boards. Key members of the committee included Frank Chauvin, a local police detective and humanitarian; Herald Bastien, immigration manager for Windsor and Essex County; Ralph Talbot, the local settlement counsellor for the Canada Employment Centre; André Pilon, settlement director for the Ontario Region at Employment and Immigration Canada (Toronto); and leaders of the faith communities, including Reverend Tom Lever and Father Robert Warden.

Windsor's resettlement efforts came at a critical time during Canada's immigration history. The mass exodus of Indochinese refugees occurred between mid-1978 and 1980, with the majority of refugees arriving to Canada between 1979 and 1980. ${ }^{13}$ However, Mayor Weeks established the Mayor's Ad Hoc Committee on Indochinese Refugees towards the end of 1977, well before the majority of refugees arrived. In this respect, Windsor was at least one year ahead of the rest of Canada in preparing for the Indochinese refugees. Testimonies from people who knew Mayor Weeks confirmed that he planned ahead. Ed Agnew, for example, said, "There is no question that [Weeks] would be the type of person who would think in advance."14 What is more, the Government of Canada tabled a new Immigration Act in 1976, which introduced a novel concept of private refugee sponsorship, whereby civil society organizations or groups of individuals could sponsor the admission of refugees and members of designated classes. Canada's Private Refugee Sponsorship Program was officially launched in July $1978,{ }^{15}$ giving any "Group of Five" or more people the ability to sponsor refugees, so long as its members were Canadian citizens and/or permanent residents 19 years of age or older. ${ }^{16}$

The Mayor's Committee was established at the end of 1977, before the Government of Canada's Private Sponsorship Program was fully operative. It was thus created to ease the transition and integration of government-sponsored refugees into Canadian society. Sponsoring organizations did not have to sign a formal agreement to help in resettlement efforts. ${ }^{17}$ The group's initial goal was to resettle 20 Indochinese refugee families, ${ }^{18}$ and on 21 September 1978 the committee reported that 11 refugees had already arrived. The Mayor's Ad Hoc Committee would later be referred to as the Windsor-Essex Refugee Committee-an evolution of the Windsor Committee, which included communities in the surrounding area. ${ }^{19}$

The success of the committee was greatly due to the leadership of Mayor Weeks and Father Warden, and thus a description of the committee cannot be complete without a brief description of each. Albert "Bert" Weeks was a watchmaker who moved to Windsor from Montreal as a young man in the late 1940s. During an interview, his daughter, Elaine Weeks, recalled how her father often said he moved to Windsor because "it would be a good place to be mayor."2o After living in Windsor for only two years, Weeks grew frustrated with corruption in the city. According to an article in the Windsor Star, "The city was in turmoil. For one, the Windsor Police Department was rotten from the top down. Gambling operations and prostitution dominated the city streets. And at one point, police constables downtown routinely directed customers to these illegal joints along Pitt Street.".21

Weeks decided to put an end to the criminality by organizing a Citizens' Action Committee. Together, the group conducted a risky investigation in order to find sufficient 
evidence to bring down the police force. Weeks and the Citizens' Action Committee succeeded, and the provincial government removed the Windsor police chief and his deputy. ${ }^{22}$

After a close race in 1975, Bert Weeks finally got his wish of becoming mayor. During his tenure, he accomplished many memorable feats for the city. Weeks was a socialist concerned with the welfare of the people; but, at the same time, he was a great businessman. ${ }^{23}$ Edward "Ed" Agnew knew Mayor Weeks very well, having worked as the city's commissioner of finance for many years. In an interview with Agnew, Weeks is described as a strong businessman who sought out new partnerships and international linkages for the city. In June 1977, Weeks arranged a business trip to Europe, in order to negotiate such opportunities. Ed Agnew went with him. According to Agnew, Mayor Weeks had already decided to respond to the Indochinese refugees during this time, as he had asked Ed to be involved during their trip. ${ }^{24}$ Indeed, the Mayor's Ad Hoc Committee on Indochinese Refugees was created shortly after.

Father Robert Warden was a priest at St. Joseph's Catholic Church and, at this time, the co-founder and executive director at the Windsor Coalition for Development. Mayor Weeks was not a very religious person; however, Father Warden shared the same sense of civic duty and humanitarianism. As a result, the two were quite close. In fact, the mayor "appointed him as a liaison between the department heads and his office."25 Many were displeased with this arrangement, but Weeks knew that Father Warden shared the same socialist values and was a dominant figure in the faith community who was deeply involved with the labour movement of the Canadian Auto Workers (CAW) at the time. These networks would prove to be useful in garnering public support and cooperation for the city's humanitarian initiatives. ${ }^{26}$ Archival records also indicate that Father Warden acted as an unofficial director of the mayor's committee, as many letters of correspondence were addressed to his office. ${ }^{27}$

Next, the Friendship Families program was created by the Mayor's Ad Hoc Committee on Indochinese Refugees to complement government sponsorship. Volunteer families were recruited from at least 10 different religious congregations, local non-governmental organizations, and the general public to help welcome newcomers and integrate them into Canadian society. ${ }^{28}$

Friendship Families greeted newcomers at the airport and helped them settle into their new homes. Refugees were then given "at least three days to rest and relax, before visiting with people from the congregations." 29 They were given an orientation session into Canadian life, and accompanied to file for Social Insurance Numbers and the Ontario
Health Insurance Plan (OHIP). Volunteers aided the new Windsorites with finding suitable employment, and helped them complete basic errands, including grocery shopping and the compilation of forms and applications. Perhaps most importantly, the local volunteers helped the refugee children settle into their new schools, often helping the chil dren with their homework.The Friendship Families gained just as much from the experience as the refugees did, with one family claiming, "It has been an education on how the other half of the world lives." 30

Significant sponsor "families" included members from Most Precious Blood Parish, Knox Presbyterian Church, Glenwood United Church, and St. Joseph's Church. The University of Windsor's Department of Political Science also sponsored a family with cooperation from other departments, and provided the financial resources to put them up in a house on Sunset Street, the campus artery. ${ }^{31}$ In 1980, the Windsor-Essex YMCA also became involved with resettlement efforts, under the coordination of Madeline Harden. The local branch provided funding mainly for recreational activities and English language classes, with money obtained from the Regional Settlement Office's Immigrant Settlement and Adaptation Program budget. ${ }^{2}$

Despite the relative success of the Windsor program, the experience of resettling the Indochinese refugees into "Rose City" was not all roses. At the time, Ralph Talbot was the counsellor at Canada Employment Centre's Windsor branch and an active member of the mayor's committee. In a report written by him for the Canadian Immigration Historical Society, Ralph explains how initially the Windsor community was hesitant about "adding a large group of visible minorities to the workforce." 33 As a result, he, the mayor, and "local church leaders from all denominations" met to discuss a strategy that would boost political and social support. The mayor's committee emerged from these meetings.

In an interview, Talbot describes a memorable moment at the beginning of the refugee program that shook the Windsor group. A local family was at the airport to welcome a group of refugees. It was the dead of winter, and when the group got off the airplane, they were dressed in thin clothes and sandals, many also in poor health. This event was a rude awakening and made the Windsor resettlement leaders realize that more people from the community had to be involved in this important endeavour. In Ralph's words, "It lit the fire and sparked the community."34

Moreover, in 1978 the city was not as ethnically diverse as it is now, and there were unfortunate manifestations of racism. ${ }^{35}$ In 1981, for example, a 15-year-old Vietnamese boy was hospitalized in the Intensive Care Unit, after being severely beaten at W. D. Lowe Secondary School. ${ }^{6}$ Ralph Talbot further indicated that racism was present even within the 
offices of the local Canada Employment Centre, as became evident when a young Indochinese refugee he had hired suddenly quit. After pressing for an explanation, the young man admitted that he had been subject to "slurs of racial, cultural nature . . by a few of the staff." 37 Racism was a problem all sponsor communities were facing, however, and was not limited to Windsor.

In addition, some locals felt that Windsor was ignoring its own people, arguing that the support that refugees received outweighed the support given to native Windsorites in need. A member of the Windsor Housing Authority declared, "Vietnamese 'boat people' have no business taking up space in public housing units." Instead, he believed that Windsor had "a responsibility to Canadian citizens first." 38 Yet, regardless of criticisms and setbacks, the Windsor community was largely very accepting of the Indochinese refugees, and there are several accomplishments worth noting.

According to a report issued by Employment and Immigration Canada, Windsor ranked fifth in the province for the number of refugees resettled between 1979 and 1980.39 In addition, Windsor was "able to maintain an $85 \%$ employment rate within the first 6-8 months of arrival for heads of households, for several years in the early 1980's."40

It would seem that the Windsor program also proved successful in integrating children into the education system. In separate interviews, Amy and Yung Hoang describe their experiences as refugee children integrating into the Canadian school system in 1980. Yung explained how the help he received from volunteers at the Knox Presbyterian Church in Leamington "profoundly affected him." Yung was one year behind in school, and when the church realized this, volunteers spent the entire summer teaching him the Grade 1 curriculum, so that by September, he would be in the same class as his age-cohort. He describes his family's "integration into the Canadian education system" as "pretty seamless" and told how this tremendous help set the course for who they are today-all successful professionals. ${ }^{41}$ His sister Amy reinforced this sentiment and said, "Our family could not have been successful without the help of the com munity." Amy added that the Presbyterian Church became "like a second family" to the Hoangs, and the Reid family, in particular, remains a part of their lives. $4^{2}$

This sentiment was also echoed by Hai Nguy, a former boat person and important member of the local Vietnamese community. Mr. Nguy described how locals often commented on the achievements of Vietnamese children at school. His two children, who escaped with him and his wife, are both successful professionals. ${ }^{43}$

Moreover, the Windsor resettlement program was an original model, created by the mayor and members of the Mayor's Ad Hoc Committee. This assumption was confirmed in an interview with Ralph Talbot: I asked whether the committee was based on any pre-existing models; Ralph immediately and confidently said, "No. The program was our idea." 44 These findings challenge the current narrative that large Canadian cities, like Ottawa and Toronto, were the first to resettle Indochinese refugees. 45 Mr. Talbot confirmed this theory and stated that while large Canadian cities were the leaders in resettling large numbers of refugees, Windsor was the leader in resettlement. Indeed, other Canadian resettlement projects such as Operation Lifeline and Project 4000 were developed later.

By the summer of 1979, the number of escapees reaching the shores of Southeast Asia reached record numbers, and Canadians, overwhelmed by the tragic media reports, decided enough was enough. Howard Adelman, a professor at York University in Toronto, was stunned by the humanitarian emergency and decided to do something about it. He called a meeting with the aim of writing a letter to the new minister of employment and immigration, Ron Atkey, and invited "a local Catholic priest, two rabbis, an alderman and ministers from the Anglican and United Churches to his house to discuss the crisis." To his surprise, André Pilon and Bob Parkes - civil servants from the Ontario settlement office of Citizenship and Immigration Canada-knocked on his door and asked to join. Mr. Pilon told the group about the new private sponsorship provision in the 1976 Immigration Act-a provision not many quite yet understood-and suggested that the group use it to "actually [do] something." 46 Dick Beddoes, a columnist for the Globe and Mail, heard about the event from a graduate student who sat in on the meeting. Beddoes decided to write about it, dubbing the initiative "Operation Lifeline." The rest is history. Requests to join Adelman's team came pouring in, and within less than two weeks, there were 68 chapters of Operation Lifeline across the country.

At the same time, Ottawa Mayor Marion Dewar was troubled by the plight of the Southeast Asian boat people. She organized a meeting with local leaders and civil servants and was informed that half of the Canadian quota to resettle 8,00o refugees had been reached. In an article written by Peter Goodspeed, Ms Dewar reflects on her decision: "I said, 'You've only got 4,00o left? We'll take them."'47 Thus, Project 4000 was born.

In 1980, Ottawa was discussing the creation of a Friendship Program to "match Canadian families or individuals with government-sponsored refugees." 48 The Ottawa Friendship Program was a joint effort of Project 400o, the Ottawa-Carleton Immigrant Services Organization (ociso), and the Catholic Immigration Services (CIS), and was later renamed Canadian Friends. According to Pat Marshall from the Ontario Host Coordination Project, a consultant 
by the name of Max Brem was researching refugee needs for Employment and Immigration Canada between 1981 and 1982, and promoted the Canadian Friends Program. Employment and Immigration decided to fund the initiative, renaming it the Host Program, and by the mid-1980s, it had expanded across the country. 49

While Operation Lifeline and Ottawa's Canadian Friends Program are well-known, they were established in 1979 and 1980 respectively-well after the Windsor program had already been established. Is it possible that the Windsor experience was used as a model? This exploratory study suggests that it was, and that the Windsor program received both national and regional attention.

\section{Windsor's Committee on Indochinese Refugees: A Model?}

\section{National Attention}

In 1977, Bud Cullen, Canadian minister of employment and immigration, announced that Canada would establish a program to admit 50 refugees from Southeast Asia per month, and an agreement was negotiated with Quebec, in this regard. On 13 January1978, Deputy Minister Jack Manion wrote Cullen to notify him of Quebec's agreement, also informing him that the mayor of Windsor had expressed an interest in assisting Indochinese refugees:

You will be interested to learn that we have been contacted by two groups that are interested in assisting small boat escapees to settle here. The Canadian Catholic Organization for Development \& Peace, operating from the Office of Archbishop Carney of Vancouver, has expressed an interest in setting up a nationwide program of assistance for boat escapees. At the same time, a committee recently established by the Mayor of Windsor has also expressed interest in assisting. We plan to give these groups every possible encouragement as they could be instrumental in generating broader public support for this program as well as in assisting individual refugee families to establish themselves here..$^{50}$

This letter demonstrates that Windsor was one of the very first cities to organize itself in anticipation of the Indochinese refugee movement. This indication is confirmed in a June 1978 telex from Canadian immigration officers in Singapore, which thanked the Windsor committee, stating, "Windsor was the leading city in sponsoring refugees." 51

André Pilon's presence at the Windsor Committee meetings is also extremely significant. Mr. Pilon was Citizenship and Immigration Canada's settlement director for the Ontario Region. As such, he oversaw operations across the province and reported any developments back to the federal offices in Ottawa. His physical presence and involvement with the Windsor group, along with his colleague Bob Parkes, illustrates that the Windsor model was of interest beyond the local level..$^{2} \mathrm{Mr}$. Pilon was most likely intrigued about the Windsor program and transferred his observations to the national ministry and the rest of the province. In fact, Ralph Talbot explained how Mr. Pilon and his Toronto office promoted and encouraged the Windsor Employment Office to carry on their work on the refugee file. They were pleased with the project that originated from Windsor and worked with others to transfer the model elsewhere. Over a year later, in the summer of 1979, André Pilon showed up at Howard Adelman's home-again, with Bob Parkes-for a meeting, which now marks the genesis of Operation Lifeline. It was Pilon who suggested the group use the new private sponsorship provision of the 1976 Immigration Act to resettle boat people locally.53 Within days, the news of Operation Lifeline spread throughout Canada. Mr. Talbot also recalls from his collaboration with the Toronto office that, because of their dedication, the Ontario region and Mr. Pilon's team led in advising headquarters about resettlement initiatives between 1979 and 1980 .

Further evidence of Windsor's outreach is found in a letter from Employment and Immigration Canada to Father Robert Warden on 21 July 1978. The letter announces that 11 families have been selected for Canadian resettlement from a small boat anchored at Singapore, named the cys Hope, and acknowledges the Mayor's Ad Hoc Committee on Indochinese Refugee group's "willingness . . . to help the small boat escapees establish in Windsor." As such, Employment and Immigration Canada requested that Windsor take in three families, in addition to a 17-year-old boy, whose parents "could only pay for his escape."54 A telex issued "on behalf of the United National High Commissioner for Refugees" compliments this letter and confirms that refugees from this group landed in Windsor in September 1978.55 This letter and telex also illustrate that Windsor initiated the resettlement of refugees well before the massive refugee movement commenced in 1979.

Furthermore, in October 1978, a boat carrying 2,500 refugees from Vietnam was refused entry into Malaysia. The Hai Hong remained anchored off the coast, without sufficient food, water, or medical supplies..$^{6}$ On 14 November 1978, Mayor Bert Weeks wrote to Bud Cullen to update him on the activities of the Mayor's Ad Hoc Committee. (A copy was sent to then Prime Minister Pierre Trudeau and local members of Parliament.) The main purpose of the letter, however, was to urge the Canadian government to do something about the Hai Hong crisis. The mayor wrote, "While we recognize the effort already being made by your Government on behalf of Indo-Chinese refugees, a special gesture of humanitarianism would appear to be warranted in this situation. If Canada would for example, announce a willingness to accept an additional 500 persons, beyond the numbers already agreed to, it could serve to inspire other countries to act on behalf of the remainder."57

(C) Giovanna Roma, 2015. This open-access work is licensed under a Creative Commons Attribution-NonCommercial 4.0 International License, which permits use, reproduction and distribution in any medium for non-commercial purposes, provided the original author(s) are credited and the original publication in Refuge: Canada's Journal on Refugees is cited. 
A few days later, Minister Cullen announced that Canada would accept 604 Hai Hong refugees. Other countries followed suit, as per Weeks's prediction..$^{8}$ Was Minister Cullen influenced by Mayor Weeks's letter? Interviewees say he probably was. 59 The letter also proves that Minister Cullen and Mayor Weeks had already been in contact earlier in the year, as the mayor cites past correspondence.

In sum, these primary sources are significant, as they demonstrate that the Windsor model did, indeed, receive national attention and suggest the possibility that Windsor may have very well influenced Canadian policy. It would be interesting to explore this last point in greater depth through additional research.

\section{Regional Attention}

As one of the first cities to organize itself in anticipation of the flood of Indochinese refugees, the Windsor program received regional attention, particularly from Edmonton, Alberta. In October 1978, Alice Colak from the Catholic Services of Edmonton wrote to churches throughout the city, alerting them to the growing refugee crisis and the possibility of sponsoring refugees under the new sponsorship program created by the 1976 Immigration Act. The letter explains how committees have already been established throughout the nation to assist resettlement of refugees in Canada, and cites Windsor as a prime example. The letter also encloses an article about the "project in Windsor, Ontario."6o

The public reception of the Windsor resettlement model must have been favourable because on 23 November 1978, Father Warden was invited to be a lead speaker at a workshop organized by the Edmonton Catholic Immigrant Services and Social Justice Commission, regarding the "Sponsorship of Vietnamese Refugees." Father Warden was to inform the audience about the experiences of the Windsor "Committee Concerning Vietnamese Refugees."61

Between late 1979 and the early 1980s, Ralph Talbot also recalls attending several conferences across the province to promote the Windsor experience, in addition to Calgary (Alberta) and Quebec. These gatherings took place in order to understand what was happening across the country and to share best practices. Mr. Talbot remembers jokingly telling other representatives that the national response started in Windsor: "We did it before you," he would say in good humour.

These pieces of primary information confirm that the Windsor program may have very well been used as a model for other communities. Unfortunately, sources that discuss Windsor's Friendship Families program are in short supply. From the information obtained, however, it would seem that the program was a precursor to Canada's Host
Program and Operation Lifeline. The extent to which the Windsor model influenced these well-known initiatives, however, is unknown and would be a fascinating topic for future studies.

\section{Concluding Remarks}

This article has described the Windsor resettlement program during the Indochinese refugee movement, comprising both the Mayor's Ad Hoc Committee on Indochinese Refugees and the Friendship Families program. It has demonstrated how the Windsor program gained national and regional attention, and may have served as a model for communities beyond even Ontario, predominantly in Alberta. Several conclusions and lessons can be learned from this case study experience.

First, Windsor's local efforts to sponsor and integrate Indochinese refugees into Canadian society seem to have been ground-breaking. This article has illustrated how the Windsor model-comprising the Mayor's Ad Hoc Committee on Indochinese Refugees and the Friendship Families program-was an original and avant-garde model, as it was organized well before the "flood of refugees" arrived in 1979. This evidence challenges the national narrative that large Canadian cities led in resettling the boat people. What is more, archival documents have illustrated that this local model received national and regional attention and may have inspired national action from the minister of employment and immigration, Bud Cullen. It was also instrumental in gaining wider public support in the country, particularly in Edmonton. Indeed, Windsor was pivotal in shaping the Canadian response to the Indochinese refugee crisis.

Although the community was legally responsible for the well-being of the refugees only one year from their arrival, the friendships and bonds that grew out of the Windsor resettlement initiatives lasted a lifetime. There are important lessons and best practices that can be drawn from Windsor's seminal efforts. These lessons include the importance of strong leadership, community engagement, and multilevel partnerships. Future studies could compare local Canadian models or explore the extent to which the Windsor model was transferred elsewhere.

By recounting this untold piece of local history, I hope readers have a greater appreciation for the important role localized communities play in forging responses to humanitarian crises. Today, the world is facing another humanitarian crisis of global proportions, and Canada is leading in resettlement efforts. ${ }^{62}$ I would encourage all those working towards this end to be cognizant of the impact of their efforts and to preserve their records, so that historians will be able to measure their impact for generations to come. 


\section{Notes}

1 Peter Duschinsky, "The Human Side of the Fall of Saigon," CIHS Bulletin 73 (April 2015): 1-16, http://cihs-shic.ca/wpcontent/uploads/2015/04/Bulletin-73-Final-with-Milburncorrection.pdf.

2 Ibid.

3 Employment and Immigration Canada, "Part 1: Indochinese Refugees: The Canadian Response, 1979 and 1980," http://cihs-shic.ca/wp-content/uploads/2015/o3/Indochinese-Refugees-Cdn-Response-report-Eng.pdf, 5. See also Michael Lanphier, "Refugee Resettlement: Models in Action," International Migration Review 17, no. 1 (1983): 6.

4 Gertrud Neuwirth and Lynn Clark, "Indochinese Refugees in Canada: Sponsorship and Adjustment," International Migration Review 15, nos. 1-2 (1981): 131-40; Howard Adelman, Canada and the Indochinese Refugees (Regina: L. A. Weigl Educational Associates, 1982); Michael Lanphier, "Refugee Resettlement: Models in Action," International Migration Review 17, no. 1 (1983): 4-33; Kwok B. Chan and Doreen Marie Indra, Uprooting, Loss and Adaptation: The Resettlement of Indochinese Refugees in Canada (Ottawa: Canadian Public Health Association, 1987).

5 Linda Marshall writes about the resettlement of the Indochinese refugees in Windsor, Ontario; however, she does so from a social work perspective. The focus of the work is to evaluate needs of the local Indochinese refugees, not the actual model itself. See Linda Marshall, "An Exploratory Study on the Resettlement of the Indochinese Refugees in Windsor, Ontario" (MA thesis, University of Windsor, 1981).

6 The Windsor Star has a digital archive available online for all publications; however only editions published after 1980 are indexed. Editions preceding this date are indexed in the Windsor Public Library's card catalogue.

7 These organizations include the Windsor Coalition for Development, the local branch of Citizenship and Immigration Canada, the Windsor Essex County Local Immigration Partnership (WELIP), the local YMCA, and the Multicultural Council of Windsor and Essex County.

8 I am extremely grateful to Ralph Talbot for providing me with committee minutes from his personal files. Unfortunately, the City of Windsor archives office was not able to retrieve these files.

9 Dr. Ron Wagenberg, professor emeritus of political science, University of Windsor, in discussion with the author, 4 December 2014.

10 Best of the Times Magazine, 2006 Edition (Windsor: Walkerville Publishing 2006), 402.

11 The total number of resettled refugees is much higher, when privately sponsored refugees are taken into account. Unfortunately, I could not acquire a number of private sponsorships. Such a task requires access to the records of all private sponsors, including churches, non-governmental organizations, and groups of five or more. The groups I contacted did not keep these files on record. The number of 1,903 government-sponsored refugees is taken from the personal records of Ralph Talbot.

12 The first official, documented meeting of the Mayor's Committee took place on 15 March 1978 (see Marshall, "Exploratory Study"). However, multiple testimonies indicate that the mayor had, indeed, organized the group as early as late 1977 .

13 Frank Frost, "Vietnam, ASEAN and the Indochinese Refugee Crisis," Southeast Asian Affairs 7 (1980): 347-67.

14 Ed Agnew,former commissioner of finance at the City of Windsor, in discussion with the author, 8 December 2014.

15 Canadian Immigration Historical Society, "A Chronology of the Indochinese Refugee Movement 1975-80," http:// cihs-shic.ca/wp-content/uploads/2015/o3/A-Chronologyof-the-Indochinese-Refugee-Movement-1975.pdf.

16 For a schematic outline of the Canadian sponsorship system, see the Canadian Immigration Historical Society, "Sponsorship System," http://cihs-shic.ca/wp-content/ uploads/2015/03/Sponsorship-Chart-1978-corrected.pdf.

17 "First Vietnamese Refugees May Be Here Next Month," Windsor Star, 8 August 1978.

18 "Mayor's Committee:Vietnamese Refugees," minutes, 22 June 1978. From the personal records of Ralph Talbot.

19 Ralph Talbot,former Canada Employment Centre counsellor, in discussion with the author, 28 November 2014.

20 Elaine Weeks, daughter of Bert Weeks, in discussion with Michael Molloy and Giovanna Roma, 17 November 2014.

21 "Former Mayor Bert Weeks Possessed Vision, Courage," Windsor Star, 17 December 2010.

22 Ibid.

23 Agnew, in discussion with the author; Weeks, in discussion with Molloy and Roma, 2014.

24 Ed Agnew added that he respectfully declined the offer of being directly involved with the Committee on Indochinese Refugees because at that time, he was too busy with his own job at the City. Agnew, in discussion with the author.

25 Ibid.

26 Ibid.

27 The Indochinese Refugee Newsletters, issued by the Conservative minister of immigration, lists the Windsor Mayor's Committee on Refugees as an organization involved with refugees. The address associated with the committee is St. Joseph's Church, 4258 Seminole Street, Windsor. (See Indochinese Newsletter 1, no. 13, 18 October 1979). A second letter, from the office of Employment and Immigration Canada, Ottawa, addresses Father Robert Warden, Mayor's Ad Hoc Committee on Indo Chinese Refugees, at his church office at 686 Marentette Avenue.

28 "First Vietnamese Refugees," Windsor Star.

29 "Mayor's Committee: Vietnamese Refugees," minutes, 21 September 1978. From the personal records of Ralph Talbot.

30 Susan Semenak, "Refugee Family Ends Journey with Big Step into Citizenship," Windsor Star, 11 December 1981.

(C) Giovanna Roma, 2015. This open-access work is licensed under a Creative Commons Attribution-NonCommercial 4.0 International License, which permits use, reproduction and distribution in any medium for non-commercial purposes, provided the original author(s) are credited and the original publication in Refuge: Canada's Journal on Refugees is cited. 
31 Wagenberg, in discussion with the author.

32 Talbot, in discussion with the author; Marshall, "Exploratory Study," 16. I also spoke to the current general manager of settlement and integration, who was able to confirm the YMCA's past involvement.

33 Ralph Talbot, "South East Asian Refugee Settlement in Windsor, on," for the Canadian Immigration Historical Society, 2013.

34 Talbot, in discussion with the author.

35 Ibid.; see also Ralph Talbot, "Racists Hurt Themselves," Windsor Star, 31 August 1982.

36 Marshall, "Exploratory Study," 19; "Racism: Air Needs to Be Cleared," Windsor Star, 25 March 1981, p. 8.

37 Talbot, in discussion with the author.

38 "wha Official Blasts Housing of Refugees," Windsor Star, 22 November 1979.

39 Employment and Immigration Canada, "Part 2: Indochinese Refugees."

40 Talbot, "South East Asian Refugee Settlement."

41 Yung Hoang is a professional engineer and an engineering director at Amec Foster Wheeler, Nuclear Canada, Toronto. Amy is a teacher at the David Suzuki School in Windsor, Ontario. Their sister Stephanie is an interior designer and their brother Adam works in information technology. Yung Hoang, in discussion with the author, 12 March 2015.

42 Amy Hoang, teacher, in discussion with the author, 16 March 2015.

43 Hai Nguy, owner of Hai-Ho Furniture, in discussion with the author, 16 March 2015.

44 Talbot, in discussion with the author.

45 The concept of a "narrative" was borrowed from conversations with Prof. Michael Molloy.

46 Peter Goodspeed, "Can Canada Duplicate Its Boat People Rescue with Syrian Refugees?” Toronto Star, 26 September 2014, http://www.thestar.com/news/atkinsonseries /2014/og/26/can_canada_duplicate_its_boat_people_rescue_with_syrian_refugees.html.

47 Ibid.

48 Pat Marshall, "From Friends to Hosts to Friends," CIHS Bulletin 55 (2009): 1-3.

49 Ibid.

50 Jack L. Manion, deputy minister, to Bud Cullen, minister of employment and immigration, 13 January 1978, Refugees and Displaced Persons, Special Movements, Indochinese, file 8700-15, vol. 1838, RG 76, Library and Archives Canada.

51 Committee Minutes, 8 June 1978; see Marshall, "Exploratory Study," 7.

52 Both Pilon and Parkes were present at a Mayor's Committee meeting on 22 June 1978.

53 Goodspeed, "Can Canada Duplicate Its Boat People Rescue."

54 Employment and Immigration Canada to Father Robert Warden, 21 July 1978.

55 Y. Y. Kim, resident representative, on behalf of the United Nations high commissioner for refugees, telex, 4 July 1978. Letter obtained from an anonymous source.

56 Dara Marcus, “The Hai Hong Incident: One Boat's Effect on Canada's Policy towards Indochinese Refugees," Canadian Immigration and Historical Society, http://cihs-shic. ca/wp-content/uploads/2013/10/Marcus_IMRC_Submission.pdf.

57 Mayor Bert Weeks to Bud Cullen, minister of employment and immigration, 14 November 1978.

58 Dara Marcus, "Saving Lives: Canada and the Hai Hong," Bout de Papier 28, no. 1 (2013): 26.

59 Indeed, Mayor Weeks's daughter, Elaine, says that the fact Cullen announced his decision regarding the Hai Hong just days after receiving her father's letter "probably wasn't a coincidence." Minister Cullen represented the SarniaLambton riding from 1968 to 1984 (a riding in Southwestern Ontario, like Windsor), and he would have certainly known Mayor Weeks, as well as the city's humanitarian reputation.

60 Alice Colak, Edmonton Interfaith Immigration Committee, Catholic Social Services, Edmonton, 26 October 1978.

61 Catholic Social Services of Edmonton, "Sponsorship of Vietnamese Refugees," 13 November 1978.

62 Adrian Edwards, "Needs Soar as Number of Syrian Refugees Tops 3 Million," UnHCR, 29 August 2014, http://www .unhcr.org/53ff76c99.html.

Giovanna Roma was a research associate at the University of Windsor from 2013 to 2015. The author may be contacted at giovannaroma2@gmail.com

(C) Giovanna Roma, 2015. This open-access work is licensed under a Creative Commons Attribution-NonCommercial 4.0 International License, which permits use, reproduction and distribution in any medium for non-commercial purposes, provided the original author(s) are credited and the original publication in Refuge: Canada's Journal on Refugees is cited. 